medRxiv preprint doi: https://doi.org/10.1101/2021.11.11.21266202; this version posted November 12, 2021. The copyright holder for this preprint (which was not certified by peer review) is the author/funder, who has granted medRxiv a license to display the preprint in It is made available under a CC-BY-NC-ND 4.0 International license .

\title{
Intraoperative localization and preservation of reading in ventral occipitotemporal cortex
}

\author{
Oscar Woolnough ${ }^{1,2}$, Kathryn M. Snyder ${ }^{1,2}$, Cale W. Morse ${ }^{1,2}$, \\ Meredith J. McCarty ${ }^{1,2}$, Samden D. Lhatoo ${ }^{2,3}$, Nitin Tandon ${ }^{1,2,3 *}$
}

${ }^{1}$ Vivian L. Smith Department of Neurosurgery, McGovern Medical School at UT Health Houston, Houston, TX, 77030, United States of America

${ }^{2}$ Texas Institute for Restorative Neurotechnologies, University of Texas Health Science Center at Houston, Houston, TX, 77030, United States of America

${ }^{3}$ Memorial Hermann Hospital, Texas Medical Center, Houston, TX, 77030, United States of America

* Correspondence: nitin.tandon@uth.tmc.edu 
medRxiv preprint doi: https://doi.org/10.1101/2021.11.11.21266202; this version posted November 12, 2021. The copyright holder for this preprint (which was not certified by peer review) is the author/funder, who has granted medRxiv a license to display the preprint in It is made available under a CC-BY-NC-ND 4.0 International license.

\section{Abstract}

Resective surgery in language-dominant ventral occipitotemporal cortex (vOTC) carries the risk of causing impairment to reading. As it is not on the lateral surface, it is not easily accessible for intraoperative mapping and extensive stimulation mapping can be time consuming. Here we assess the feasibility of using task-based electrocorticography (ECoG) recordings intraoperatively to help guide stimulation mapping of reading in vOTC.

In 11 patients undergoing extraoperative, intracranial seizure mapping we recorded induced broadband gamma activation $(70-150 \mathrm{~Hz})$ during a visual category localizer. Word-responsive cortex localized in this manner showed a high sensitivity $(72 \%)$ to stimulation-induced reading deficits, and the confluence of ECoG and stimulation positive sites appears to demarcate the visual word form area.

In two additional patients, with pathologies necessitating resections in language-dominant vOTC, taskbased functional mapping was performed intraoperatively using subdural ECoG, alongside direct cortical stimulation. Cortical areas critical for reading were mapped and successfully preserved, while enabling pathological tissue to be completely removed. Data collection is possible in $<3$ minutes and initial intraoperative data analysis takes $<3$ minutes, allowing for rapid assessment of broad areas of cortex.

Eloquent cortex in ventral visual cortex can be rapidly mapped intraoperatively using ECoG. This method acts to guide high-probability targets for stimulation, with limited patient participation, and can be used to avoid iatrogenic dyslexia following surgery.

Keywords: Electrocorticography, Reading, Language, Awake Craniotomy, Cortical Stimulation Abbreviations: $\mathrm{ECoG}=$ electrocorticography; $\mathrm{vOTC}=$ ventral occipitotemporal cortex; VWFA = visual word form area; CSM = cortical stimulation mapping; $\mathrm{FCD}=$ focal cortical dysplasia. 
medRxiv preprint doi: https://doi.org/10.1101/2021.11.11.21266202; this version posted November 12, 2021. The copyright holder for this preprint (which was not certified by peer review) is the author/funder, who has granted medRxiv a license to display the preprint in It is made available under a CC-BY-NC-ND 4.0 International license .

\section{Introduction}

Ventral occipitotemporal cortex (vOTC) contains several cortical regions dedicated to higher-level visual processing of scenes, faces, objects and words, that follow a well-characterized, medial-tolateral topography with regards to their preferred tuning. ${ }^{1-3}$ Lesions of any of these category selective regions can result in isolated deficits in a categorical domain, such as prosopagnosia or scene agnosia. ${ }^{4,5}$ In particular, the visual word form area (VWFA), located in the lateral aspect of language-dominant vOTC, displays category selectivity to written words, as demonstrated by functional imaging and direct cortical stimulation, ${ }^{6-9}$ and lesions that result in alexia. ${ }^{10,11}$ Given the critical role of reading in modern life, it is imperative to localize and preserve reading sites in vOTC to enable safe resective procedures in this region.

Direct cortical stimulation during an awake craniotomy is the widely accepted gold-standard for localizing and preserving critical language regions. ${ }^{12,13}$ This enables optimal resections while preserving cognitive function. ${ }^{14,15}$ However, performing intraoperative stimulation of the ventral surface of the temporo-occipital region is challenging given limited access, additional intraoperative time, and a high level of patient engagement required for comprehensive mapping of reading function. ${ }^{13}$ Electrocorticography $(\mathrm{ECoG})$ has been widely used in the extraoperative setting to localize seizure foci in patients with drug-resistant epilepsy and for basic insight into cognitive functions. Previous studies have shown that extraoperative ECoG and cortical stimulation can co-localize language processes, ${ }^{16-19}$ including for naming, ${ }^{20}$ speech, ${ }^{21}$ and reading ${ }^{8,9}$ tasks, in reliable and concordant fashion. Furthermore, mapping category selectivity of word-selective cortex with these tasks can be performed rapidly and does not necessitate subject participation. ${ }^{22}$ This suggests that taskbased ECoG may be an effective method of guiding and increasing efficiency of intraoperative stimulation of vOTC. Here we assess the use of extraoperative and intraoperative recordings alongside stimulation mapping to identify and preserve eloquent reading cortex in lateral vOTC while enabling resection of pathological tissue.

\section{Materials and Methods}

\section{Participants}

13 patients (6 male, 18-47 years, all right-handed, IQ $94 \pm 8$, Age of Epilepsy Onset $18 \pm 9$ years) were semi-chronically implanted with intracranial electrodes for seizure localization of pharmaco-resistant epilepsy. Eleven patients participated in an extraoperative visual category localizer task and underwent extraoperative cortical stimulation mapping. Two patients (P1, P2), detailed below, performed an intraoperative category localizer and underwent direct cortical stimulation during an awake resective 
medRxiv preprint doi: https://doi.org/10.1101/2021.11.11.21266202; this version posted November 12,2021 . The copyright holder for this preprint (which was not certified by peer review) is the author/funder, who has granted medRxiv a license to display the preprint in

It is made available under a CC-BY-NC-ND 4.0 International license .

craniotomy. All participants gave written informed consent and all experimental procedures were reviewed and approved by the Committee for the Protection of Human Subjects (CPHS) of the University of Texas Health Science Center at Houston as Protocol Number HSC-MS-06-0385.

\section{Functional Imaging}

Task-based fMRI data were acquired using a gradient-recalled echo-planar imaging sequence consisting of 33 axial slices with $3 \mathrm{~mm}$ thickness and in-plane resolution of $2.75 \mathrm{~mm}$ isotropic $(\mathrm{TE}=$ $30 \mathrm{~ms}, \mathrm{TR}=2,015 \mathrm{~ms}$, flip angle $=90^{\circ}$ ).

\section{Category Localizer}

Stimuli were presented on an LCD screen positioned at eye-level, approximately $50 \mathrm{~cm}$ from the patient. 60 (P1, Extraoperative) or 40 (P2) each of (i) words, (ii) faces, (iii) consonant strings and (iv) phase-scrambled faces were presented in pseudorandom order at an approximate size of $9^{\circ}$ visual angle (Figure 1A). ${ }^{22}$ Stimuli were presented using Psychophysics Toolbox in MATLAB. Each image was displayed for $750 \mathrm{~ms}$ (P1, Extraoperative) or $500 \mathrm{~ms}$ (P2) with an inter-stimulus interval of $500 \mathrm{~ms}$. Total stimulus presentation time for $\mathrm{P} 1$ was $<7$ minutes and for $\mathrm{P} 2$ was $<3$ minutes. To ensure attention, 20 images were presented twice in a row, which the patients indicated by either pressing a button (Extraoperative) or saying "Repeat" aloud (P1, P2). Repeat trials were not included in the analysis.

\section{Signal Analysis}

Extraoperative data were acquired from either subdural grid electrodes (2 patients) or stereotactically placed depth electrodes (9 patients). Subdural electrodes were platinum-iridium electrodes embedded in a silicone elastomer sheet (PMT Corporation; top-hat design; 3mm diameter cortical contact), and were surgically implanted via a craniotomy. ${ }^{23,24}$ Stereotactic probes were implanted using a Robotic Surgical Assistant (Medtech, Montpellier, France). ${ }^{25,26}$ Each probe (PMT corporation, Chanhassen, Minnesota) was $0.8 \mathrm{~mm}$ in diameter and had 8-16 electrode contacts. Each contact was a platinumiridium cylinder, $2.0 \mathrm{~mm}$ in length and separated from the adjacent contact by $1.5-2.43 \mathrm{~mm}$.

For the intraoperative cases, ECoG electrodes were subdural platinum-iridium electrodes embedded in a silicone elastomer sheet (PMT Corporation, Manhasset, MN; top-hat design; 3mm diameter cortical contact, $0.66 \mathrm{~cm}$ interelectrode spacing). Electrodes were temporarily secured in place by suturing the connection leads to the dural edges. ${ }^{23,24,27}$ Data were digitized at $2 \mathrm{kHz}$ using the NeuroPort recording system (Blackrock Microsystems, Salt Lake City, Utah).

In the extraoperative cases, signals were re-referenced to the common average of the clean channels while for the intra-operative cases signals were referenced to an electrode on the lateral cortical surface, away from visually response regions. Trials contaminated by inter-ictal epileptic spikes were 
medRxiv preprint doi: https://doi.org/10.1101/2021.11.11.21266202; this version posted November 12, 2021. The copyright holder for this preprint (which was not certified by peer review) is the author/funder, who has granted medRxiv a license to display the preprint in It is made available under a CC-BY-NC-ND 4.0 International license.

discarded. Broadband gamma activity (BGA; 70-150Hz) was extracted with a frequency domain bandpass Hilbert transform (paired sigmoid flanks with half-width $1.5 \mathrm{~Hz}$ ) and the analytic amplitude was smoothed (Savitzky - Golay finite impulse response, $3^{\text {rd }}$ order, frame length of $201 \mathrm{~ms}$ ). BGA is presented here as percentage change from baseline level, defined as the period -500 to -100 ms before stimulus presentation. Initial data analysis and visualization for intraoperative cases was performed in the operating room, on a laptop running a MATLAB-based pipeline, in $<3$ minutes. Extraoperative electrode localization was performed by co-localizing a pre-operative MRI with the post-implantation CT. ${ }^{27}$ For post-surgical visualization of intraoperative cases, electrodes were localized manually in AFNI, based on intraoperative photographs and localizations using a surgical navigation system (StealthStation S8, Medtronic). Cortical surface reconstruction was performed using FreeSurfer and imported into AFNI where the electrode positions were mapped onto the cortical surface. ${ }^{27,28}$

\section{Cortical Stimulation Mapping}

Cortical stimulation mapping (CSM) was carried out using a Nihon Kohden PE-210A stimulator through the ECoG electrodes (Extraoperative), or with an OCS2 handheld stimulator (5mm electrode spacing; Integra LifeSciences, France) (P1, P2). 50Hz, $500 \mu \mathrm{s}$ square pulse stimulation was administered with a current between 5 and $10 \mathrm{~mA}$ depending on an established baseline that did not result in after-discharges. ${ }^{23}$ Testing included reading of standardized passages (i.e. the Grandfather, Rainbow and North Wind passages). ${ }^{9}$ Intraoperatively, visual stimuli were presented on the same screen used for the ECoG task stimuli and auditory stimuli were delivered orally by the surgeon.

\section{Results}

\section{Extraoperative Reading Mapping}

We used three different ECoG contrasts to predict stimulation induced reading deficits: (i) words > scrambled (72\% sensitivity), (ii) words $>$ consonants (24\% sensitivity) and (iii) words $>$ faces (56\% sensitivity) (Figure 1C-E). The words $>$ scrambled contrast showed the greatest overlap with the CSMpositive sites and the region of greatest concordance between ECoG and CSM was located within midfusiform cortex - the predicted location of the VWFA (Figure 1F).

Within mid-fusiform cortex, discordant results between ECoG and CSM commonly occurred at electrodes neighboring true positive electrodes. This likely reflects the lower resolution of stimulation as mostly non-overlapping pairs of electrodes were stimulated. Patients with CSM-positive, ECoGnegative electrodes in the anterior temporal lobe were notably present in patients with epileptic foci in 
medRxiv preprint doi: https://doi.org/10.1101/2021.11.11.21266202; this version posted November 12, 2021. The copyright holder for this preprint (which was not certified by peer review) is the author/funder, who has granted medRxiv a license to display the preprint in It is made available under a CC-BY-NC-ND 4.0 International license .

proximity to the site of stimulation and reported dizziness, confusion and aura-like symptoms during stimulation of these sites.

A

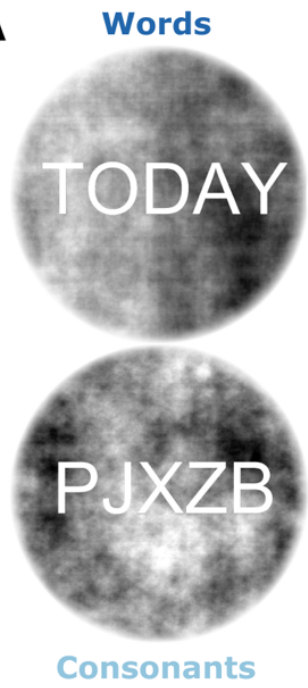

C

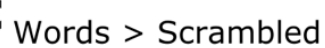

Faces

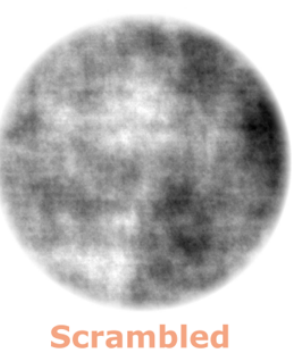

D
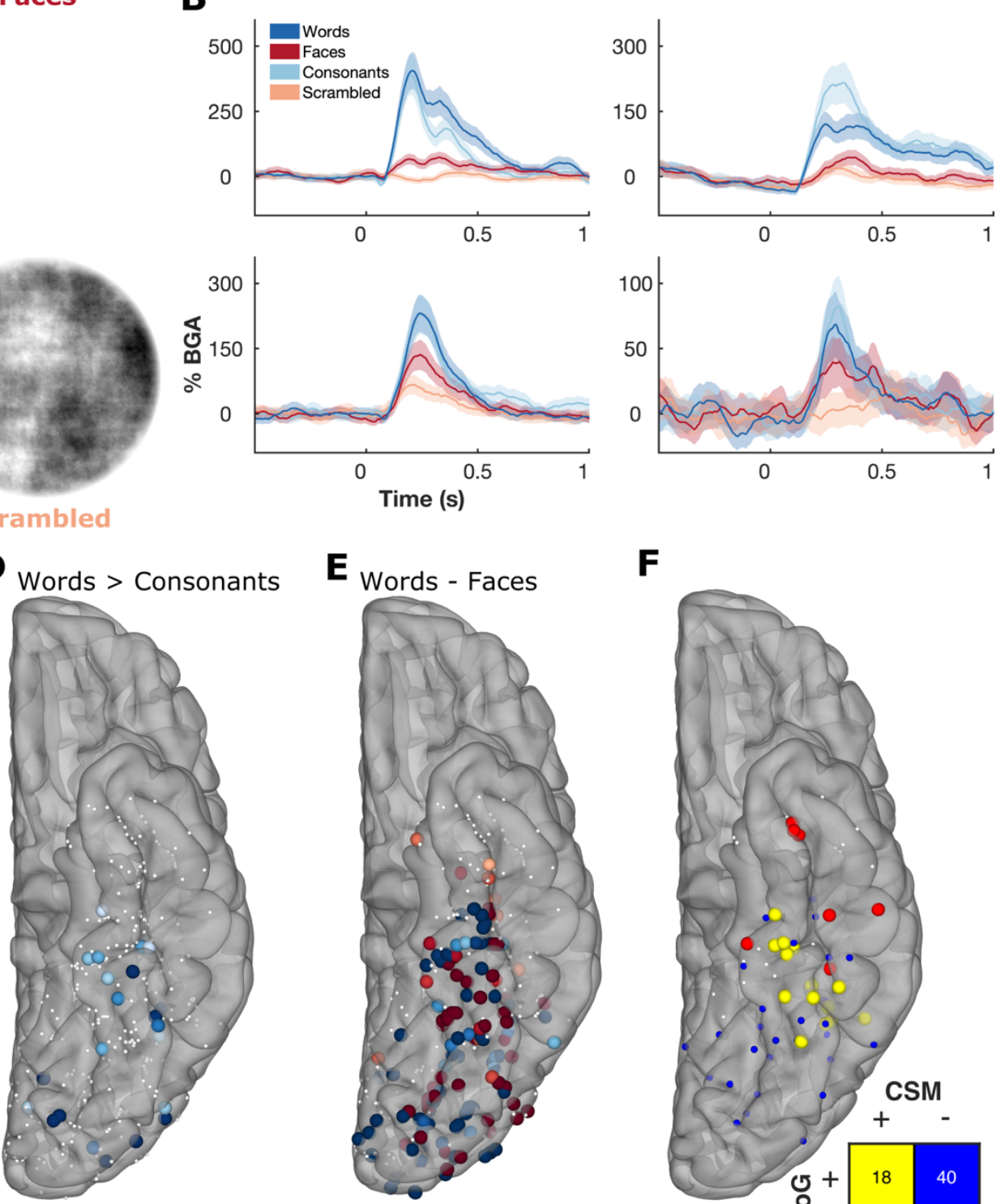

$-50$

\section{0}

\section{D \%BGA}

$\mathbf{E}$

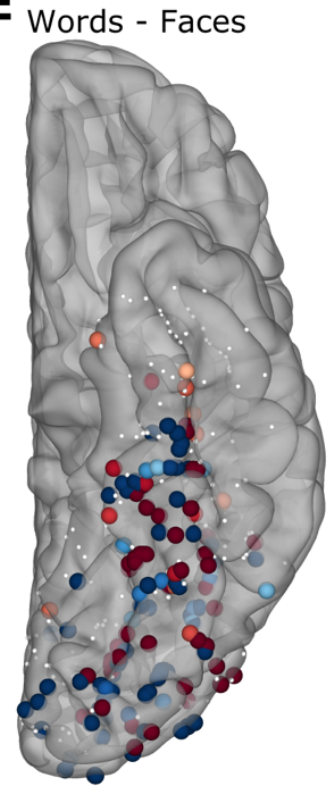

F

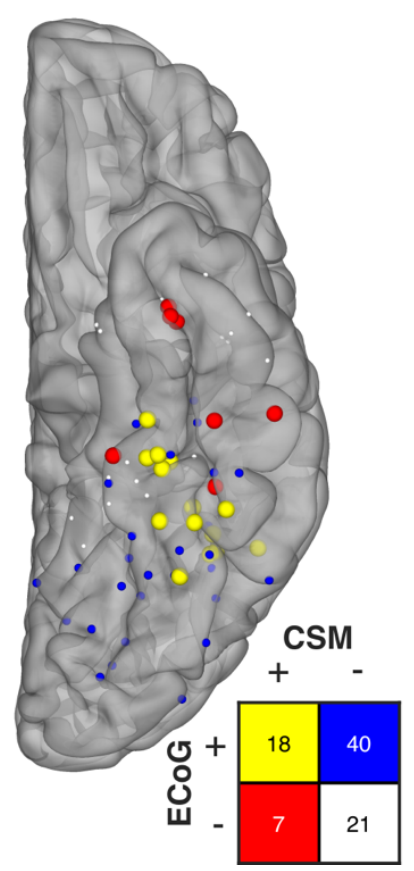

Figure 1: Extraoperative ECoG Category Selectivity. A: Example stimuli from the visual category localizer. B: Time course of broadband gamma for representative stimulation-positive electrodes from four patients. C-E: Contrasts of words $>$ scrambled (C), words $>$ consonants (D), and words - faces (E) in the window 100-400 ms after stimulus onset. Thresholded by electrodes with a significant difference (two-sample t-test, $\mathrm{p}<0.01$ ). F: Concordance between task-related activation (words $>$ scrambled; $\mathrm{ECoG}+$ ) and cortical stimulation mapping (CSM) sites, in ventral occipitotemporal cortex, leading to reading disruption $(\mathrm{CSM}+)$. CSM was performed between neighboring electrode pairs. Pairs were considered $\mathrm{ECoG}+$ if either electrode was significant. 
medRxiv preprint doi: https://doi.org/10.1101/2021.11.11.21266202; this version posted November 12, 2021. The copyright holder for this preprint (which was not certified by peer review) is the author/funder, who has granted medRxiv a license to display the preprint in It is made available under a CC-BY-NC-ND 4.0 International license.

\section{Intraoperative Category Localizer}

Two patients scheduled to undergo awake resective craniotomies in the language-dominant vOTC were recruited for intraoperative task-based ECoG mapping in addition to clinical standard language mapping.

Patient 1 (P1) was a teenage right-handed female with medication-resistant focal epilepsy, having failed treatment with Lacosamide and Lamotrigine. Seizures started as a loss of awareness with subsequent asymmetric tonic limb posturing, a right sided figure of 4 sign and right-sided facial twitching. This evolved into right hemibody clonus and then a generalized tonic-clonic seizure. Her MRI revealed a lesion in the left inferior temporal gyrus consistent with a focal cortical dysplasia (FCD) (Figure 2A-D). EEG showed inter-ictal spikes and seizure onset localized to the left posterior temporal lobe. Clinical onset of seizures preceded electrographic manifestations on EEG. Magnetoencephalographic source reconstruction localized inter-ictal discharges in the vicinity of the FCD.

Patient 2 (P2) was a right-handed male in his thirties presenting with new onset seizures resulting in aphasia. His MRI revealed a left temporal lobe tumor spanning across the inferior, middle and superior temporal gyri (Figure 2F-I).

Left hemispheric dominance of language function was confirmed with fMRI in both patients and both had word responsive fMRI clusters in close proximity to their pathological tissue (Figure 2E,J). 
A

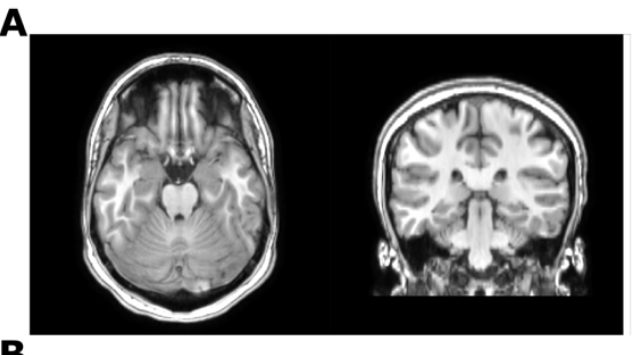

C

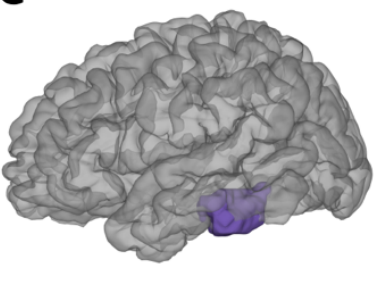

B
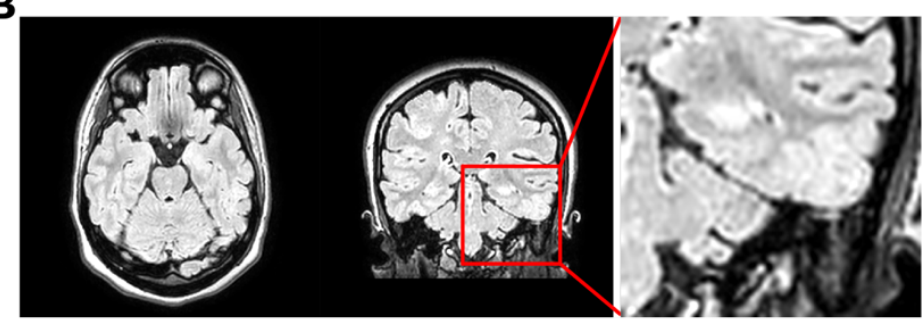

$\mathbf{F}$
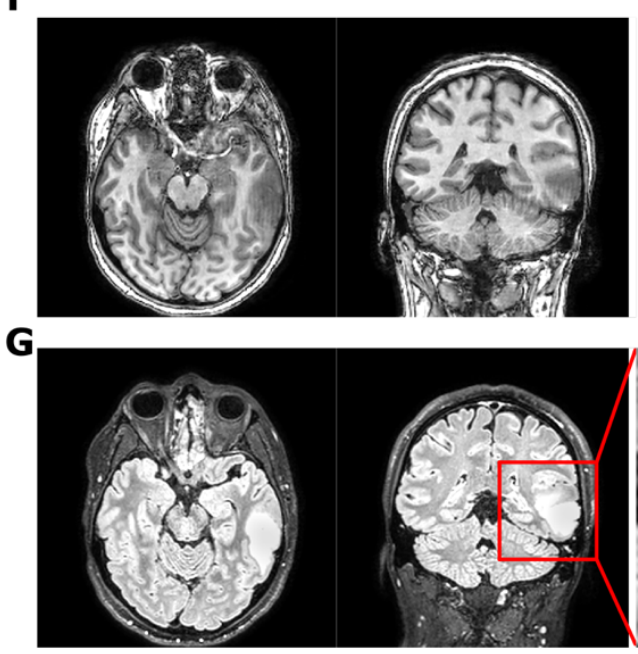

H
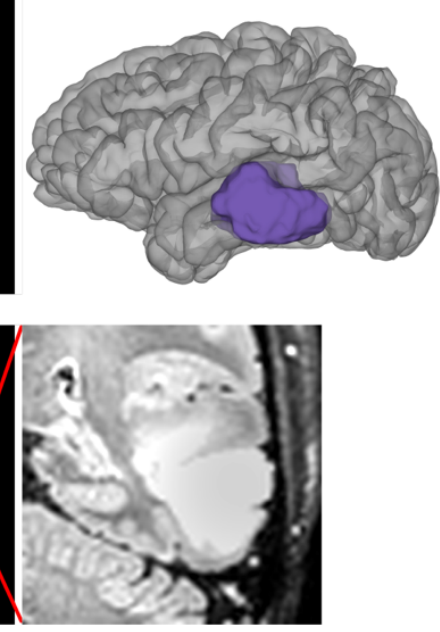

D

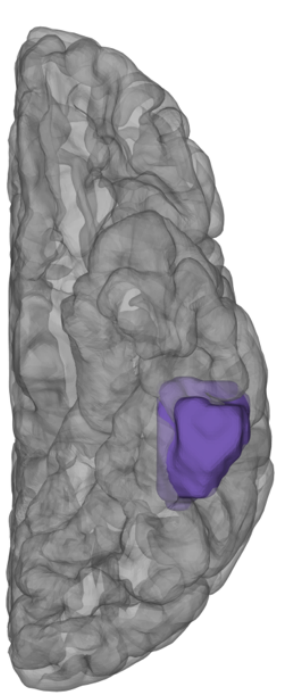

I

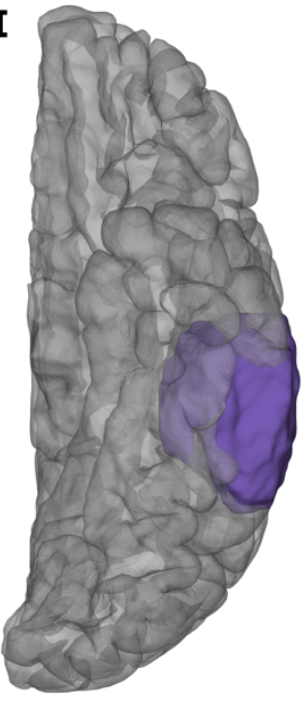

$\mathbf{E}$

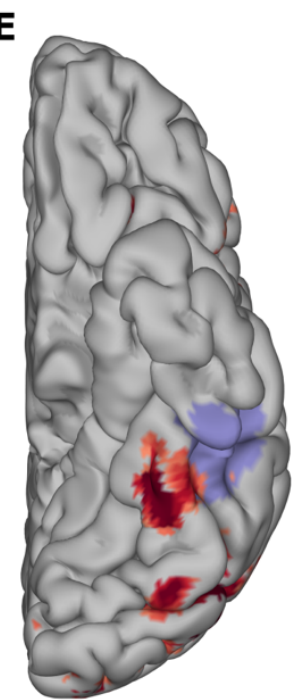

J

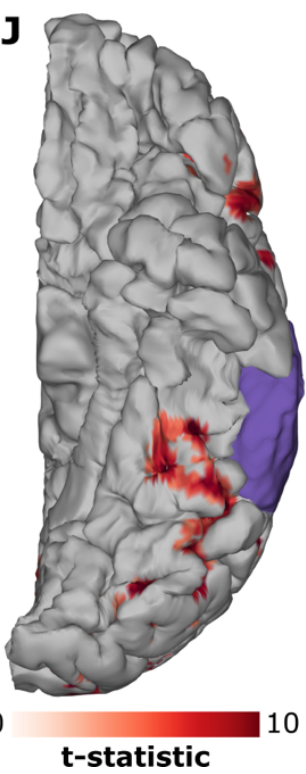

Figure 2: Preoperative Imaging. A,B,F,G: Preoperative T1 (A,F) and FLAIR (B,G) MRI imaging for P1 (A,B) and P2 (F,G). C,D,H,I: Lateral $(\mathrm{C}, \mathrm{H})$ and ventral $(\mathrm{D}, \mathrm{I})$ views of 3D reconstructions of the patients' cortical surfaces and the focal cortical dysplasia (P1; C,D) and tumor (P2; H,I), as determined from the preoperative MRI. E,J: fMRI contrast of words > fixation for P1 (E) and P2 (J) with the predicted pial involvement of the relevant pathology highlighted. fMRI thresholded at $t>5$.

Multiple electrodes demonstrated strong BGA selectivity for either words or faces (Figure 3A,B). Contrasts of words and faces demonstrated spatially contiguous clusters of strong selectivity in vOTC (Figure 3C,D). In both patients, functional BGA responses were observed around the borders of their pathological tissue, as defined by the MRI. Signal quality was comparable to that seen in the extraoperative cases and there were no notable differences in the quality of neural responses between the $<7(\mathrm{P} 1)$ and $<3(\mathrm{P} 2)$ minute versions of the paradigm. 
medRxiv preprint doi: https://doi.org/10.1101/2021.11.11.21266202; this version posted November 12, 2021. The copyright holder for this preprint (which was not certified by peer review) is the author/funder, who has granted medRxiv a license to display the preprint in

It is made available under a CC-BY-NC-ND 4.0 International license.

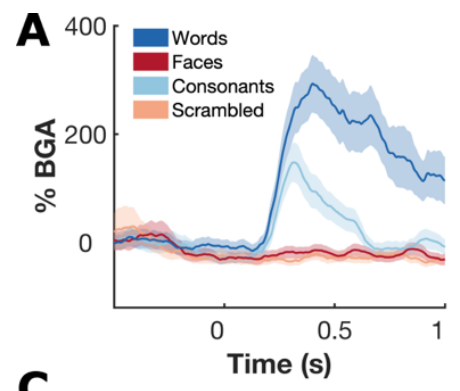

C

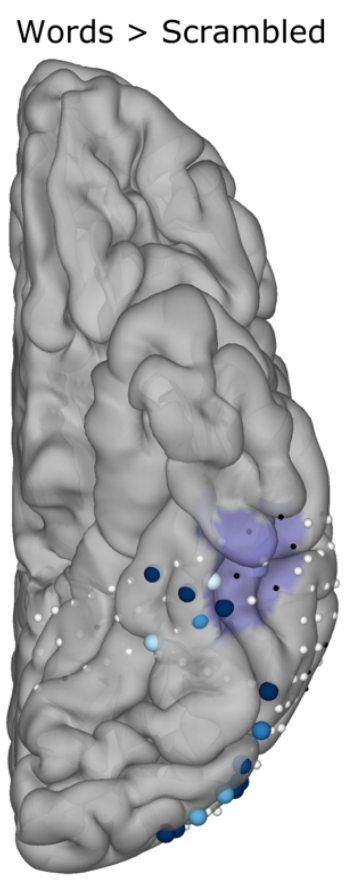

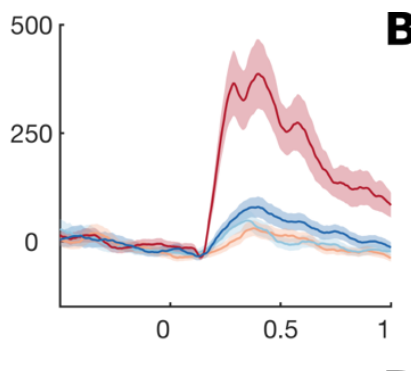

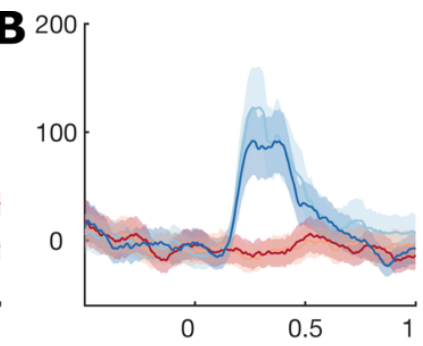

D

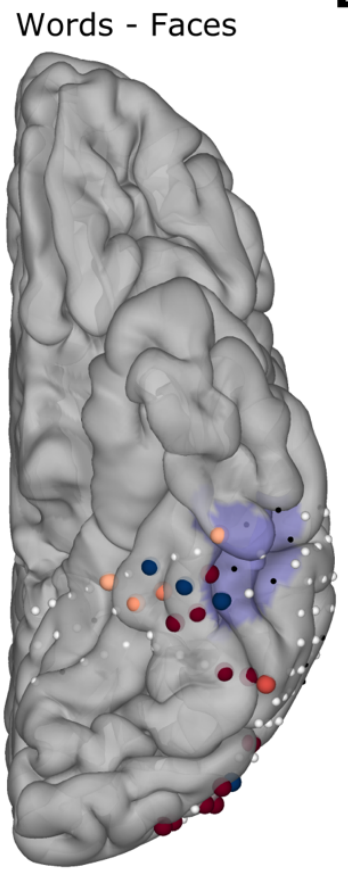

Words > Scrambled

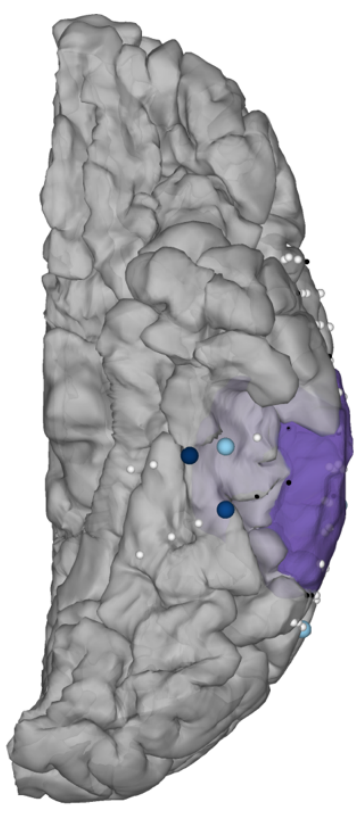

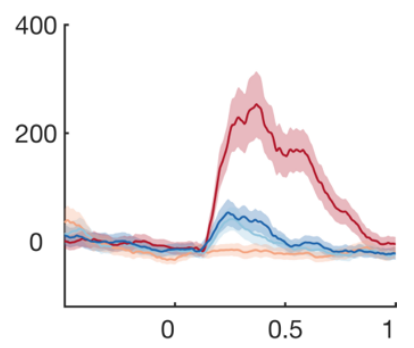

Words - Faces

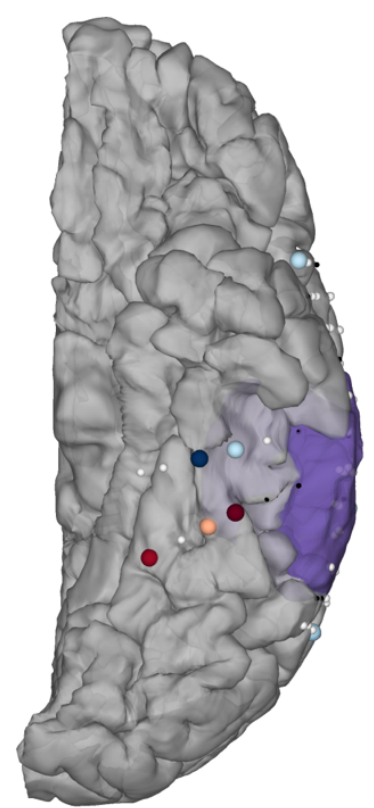

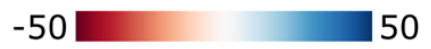

$\triangle$ \%BGA

Figure 3: ECoG Category Selectivity. A,B: Example responses of word and face selective sites from P1 (A) and P2 (B). C,D: Spatial map of contrasts of words > scrambled, and words - faces in the window 100-400 ms after stimulus onset for P1 (C) and P2 (D). Thresholded by electrodes with a significant difference (two-sample t-test, $\mathrm{p}<0.01$ ). Electrodes in black were excluded due to excessive inter-ictal spikes. Preoperative MRI-derived mask of pathological tissue is highlighted in purple.

\section{Cortical Stimulation Mapping}

In Patient 1, 10 distinct sites across lateral inferior temporal gyrus and over the FCD were tested using a handheld stimulator. All of these sites were CSM and ECoG negative.

In Patient 2, the cortical patch that showed greater BGA to words than faces was stimulated using a handheld stimulator leading to sustained reading disruption (Figure 4B). The patient's subjective reports during reading disruptions were comparable to those from previous studies of stimulation in vOTC9: "I see the words but they're not coming out of my mouth". 
medRxiv preprint doi: https://doi.org/10.1101/2021.11.11.21266202; this version posted November 12, 2021. The copyright holder for this preprint (which was not certified by peer review) is the author/funder, who has granted medRxiv a license to display the preprint in It is made available under a CC-BY-NC-ND 4.0 International license.

During the resection both patients were periodically tested, without stimulation, using the same behavioral tasks and displayed no noticeable deficits at any point.

A

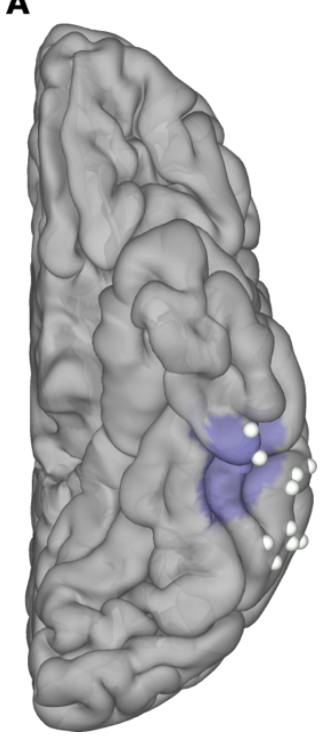

B

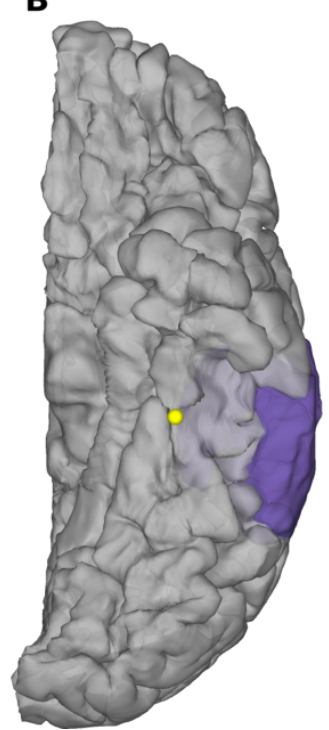

Figure 4: Intraoperative Stimulation. Stimulation testing during reading in P1 (A) and P2 (B), highlighting CSM positive (yellow) and negative (white) sites. MRI-derived mask of pathological tissue is highlighted in purple.

\section{Discussion}

Prior studies investigating the correspondence of task-based ECoG with cortical stimulation have primarily focused on higher-level language networks underlying visual naming across the lateral cortical surface. ${ }^{17-19}$ Here we show that task-based ECoG is also of utility for intraoperative mapping of ventral visual cortex, which contains several critical language sites that are mostly underappreciated in the clinical literature. Here we present evidence that intraoperative ECoG recordings in vOTC are robust, reliable and repeatable. This stimulus-induced activity can act as a rapid method of mapping function in vOTC with little active patient participation required, which further reduces the risk of functional deficits following surgery. While direct cortical stimulation is relatively time consuming, its combination with task-based ECoG increases efficiency, reduces the need for active patient participation, and provides an additional tool to localize eloquent cortex.

In the extraoperative cohort we observed a subset of sites in ventral anterior temporal lobe that resulted in stimulation-induced reading disruption but no significant ECoG activity. These sites were all anterior to regions associated with long-term reading or naming deficits as predicted by lesion studies, ${ }^{29}$ and may be more reflective of spreading effects caused by stimulation within pathological tissue. Additionally, we also observed that stimulation through the ECoG electrodes appeared to 
medRxiv preprint doi: https://doi.org/10.1101/2021.11.11.21266202; this version posted November 12, 2021. The copyright holder for this preprint (which was not certified by peer review) is the author/funder, who has granted medRxiv a license to display the preprint in It is made available under a CC-BY-NC-ND 4.0 International license .

disrupt a broader area of cortex than is highlighted by ECoG activations. There are several likely explanations for this including that: (i) ECoG activation was derived for individual electrodes however stimulation was performed on neighboring bipolar pairs. Individual electrodes can be isolated using bipolar stimulation if they result in disruption as part of multiple tested pairs ${ }^{18}$; however, given time constraints, it was not possible to stimulate all electrode pairs in these cases, and testing consisted primarily of non-overlapping electrode pairs. (ii) The effects of stimulation likely affect broader areas of cortex than the ECoG signals are recorded from. ${ }^{30}$ It is well known that, at high currents, stimulation can cause non-local effects in functionally connected regions. ${ }^{12}$

\section{Conclusions}

Given that ECoG activations are correlational rather than causal they do not act as a replacement for traditional stimulation methods. However, this method can act as an effective broad mapping tool to prioritize high probability functional regions and can serve as an additional tool when mapping eloquent cortex. While many patients would benefit from mapping techniques that require less patient participation, this mostly passive method would be of particular utility in situations where an extended stimulation mapping session is impractical, such as in patients experiencing delirium, agitation or confusion while emerging from sedation, or within pediatric populations, who often have difficulty participating in long, repetitive and highly structured tasks. ${ }^{16,17}$ Additionally, this method could be utilized in patients with seizure onset zones located in close proximity to functional tissue as stimulation-induced disruptions may reflect the induction of a localized seizure rather than direct disruption of eloquent cortex. Altogether our results support the conclusion that the confluence of ECoG activation and stimulation-induced deficits acts as a localizer of the VWFA in mid-fusiform cortex. ${ }^{9}$ As such, the use of ECoG and cortical stimulation in combination to localize brain regions essential for reading in both extraoperative and intraoperative settings is a useful approach to identify functional tissue in order to minimize postoperative reading deficits following surgical resection. ${ }^{10,11}$ 
medRxiv preprint doi: https://doi.org/10.1101/2021.11.11.21266202; this version posted November 12, 2021. The copyright holder for this preprint (which was not certified by peer review) is the author/funder, who has granted medRxiv a license to display the preprint in It is made available under a CC-BY-NC-ND 4.0 International license.

\section{Acknowledgements}

We express our gratitude to all the patients who participated in this study; the neurologists at the Texas Comprehensive Epilepsy Program who participated in the care of these patients; and the nurses and technicians in the Epilepsy Monitoring Unit at Memorial Hermann Hospital who helped make this research possible.

\section{Funding}

This work was supported by the National Institute of Neurological Disorders and Stroke NS098981.

\section{Competing Interests}

The authors report no competing interests 
medRxiv preprint doi: https://doi.org/10.1101/2021.11.11.21266202; this version posted November 12, 2021. The copyright holder for this preprint (which was not certified by peer review) is the author/funder, who has granted medRxiv a license to display the preprint in It is made available under a CC-BY-NC-ND 4.0 International license.

\section{References}

1. Kadipasaoglu CM, Conner CR, Whaley ML, Baboyan VG, Tandon N. Category-selectivity in human visual cortex follows cortical topology: A grouped icEEG study. PLoS One.

2016;11(6). doi:10.1371/journal.pone.0157109

2. Jacques C, Witthoft N, Weiner KS, et al. Corresponding ECoG and fMRI category-selective signals in human ventral temporal cortex. Neuropsychologia. 2016;83:14-28.

doi:10.1016/j.neuropsychologia.2015.07.024

3. Woolnough O, Rollo PS, Forseth KJ, Kadipasaoglu CM, Ekstrom AD, Tandon N. Category Selectivity for Face and Scene Recognition in Human Medial Parietal Cortex. Curr Biol. 2020;30(14):2707-2715. doi:10.1016/j.cub.2020.05.018

4. Duchaine B, Yovel G. A Revised Neural Framework for Face Processing. Annu Rev Vis Sci. 2015;1(1):393-416. doi:10.1146/annurev-vision-082114-035518

5. Aguirre GK, D’Esposito M. Topographical disorientation: A synthesis and taxonomy. Brain. 1999;122(9):1613-1628. doi:10.1093/brain/122.9.1613

6. Dehaene S, Cohen L. The unique role of the visual word form area in reading. Trends Cogn Sci. 2011;15(6):254-262. doi:10.1016/j.tics.2011.04.003

7. Yeatman JD, White AL. Reading: The Confluence of Vision and Language. Annu Rev Vis Sci. 2021;7(1):487-517. doi:10.1146/annurev-vision-093019-113509

8. Hirshorn EA, Li Y, Ward MJ, Richardson RM, Fiez JA, Ghuman AS. Decoding and disrupting left midfusiform gyrus activity during word reading. Proc Natl Acad Sci. 2016;113(29):8162-8167. doi:10.1073/pnas.1604126113

9. Woolnough O, Donos C, Rollo PS, et al. Spatiotemporal dynamics of orthographic and lexical processing in the ventral visual pathway. Nat Hum Behav. 2021;5(3):389-398.

doi:10.1038/s41562-020-00982-w

10. Pflugshaupt T, Gutbrod K, Wurtz P, et al. About the role of visual field defects in pure alexia. Brain. 2009;132(7):1907-1917. doi:10.1093/brain/awp141

11. Tsapkini K, Rapp B. The orthography-specific functions of the left fusiform gyrus: Evidence of modality and category specificity. Cortex. 2010;46(2):185-205.

doi:10.1016/j.cortex.2009.02.025

12. Borchers S, Himmelbach M, Logothetis N, Karnath HO. Direct electrical stimulation of human cortex-the gold standard for mapping brain functions? Nat Rev Neurosci. 
medRxiv preprint doi: https://doi.org/10.1101/2021.11.11.21266202; this version posted November 12,2021 . The copyright holder for this preprint (which was not certified by peer review) is the author/funder, who has granted medRxiv a license to display the preprint in It is made available under a CC-BY-NC-ND 4.0 International license .

2012;13(1):63-70. doi:10.1038/nrn3140

13. Mandonnet E, Herbet G. Intraoperative Mapping of Cognitive Networks. (Mandonnet E, Herbet G, eds.). Springer International Publishing; 2021. doi:10.1007/978-3-030-75071-8

14. Motomura K, Chalise L, Ohka F, et al. Neurocognitive and functional outcomes in patients with diffuse frontal lower-grade gliomas undergoing intraoperative awake brain mapping. $J$ Neurosurg. 2020;132(6):1683-1691. doi:10.3171/2019.3.JNS19211

15. Racine CA, Li J, Molinaro AM, Butowski N, Berger MS. Neurocognitive Function in Newly Diagnosed Low-grade Glioma Patients Undergoing Surgical Resection With Awake Mapping Techniques. Neurosurgery. 2015;77(3):371-379. doi:10.1227/NEU.0000000000000779

16. Roland JL, Hacker CD, Leuthardt EC. A review of passive brain mapping techniques in neurological surgery. Neurosurgery. 2021;88(1):15-24. doi:10.1093/neuros/nyaa361

17. Arya R, Wilson JA, Fujiwara H, et al. Electrocorticographic high-gamma modulation with passive listening paradigm for pediatric extraoperative language mapping. Epilepsia. 2018;59(4):792-801. doi:10.1111/epi.14029

18. Arya R, Horn PS, Crone NE. ECoG high-gamma modulation versus electrical stimulation for presurgical language mapping. Epilepsy Behav. 2018;79:26-33. doi:10.1016/j.yebeh.2017.10.044

19. Wang Y, Hays MA, Coogan C, et al. Spatial-Temporal Functional Mapping Combined With Cortico-Cortical Evoked Potentials in Predicting Cortical Stimulation Results. Front Hum Neurosci. 2021;15(April):1-13. doi:10.3389/fnhum.2021.661976

20. Forseth KJ, Kadipasaoglu CM, Conner CR, Hickok G, Knight RT, Tandon N. A lexical semantic hub for heteromodal naming in middle fusiform gyrus. Brain. 2018;141(7):21122126. doi:10.1093/brain/awy 120

21. Forseth KJ, Hickok G, Rollo PS, Tandon N. Language prediction mechanisms in human auditory cortex. Nat Commun. 2020;11(1):5240. doi:10.1038/s41467-020-19010-6

22. Kay KN, Yeatman JD. Bottom-up and top-down computations in word- and face-selective cortex. Elife. 2017;6. doi:10.7554/elife.22341

23. Tandon N. Mapping of human language. In: Yoshor D, Mizrahi E, eds. Clinical Brain Mapping. McGraw Hill Education; 2012:203-218.

24. Tong BA, Esquenazi Y, Johnson J, Zhu P, Tandon N. The Brain is Not Flat: Conformal Electrode Arrays Diminish Complications of Subdural Electrode Implantation, A Series of 117 Cases. World Neurosurg. 2020;144:e734-e742. doi:10.1016/j.wneu.2020.09.063 
medRxiv preprint doi: https://doi.org/10.1101/2021.11.11.21266202; this version posted November 12, 2021. The copyright holder for this preprint (which was not certified by peer review) is the author/funder, who has granted medRxiv a license to display the preprint in It is made available under a CC-BY-NC-ND 4.0 International license .

25. Rollo PS, Rollo MJ, Zhu P, Woolnough O, Tandon N. Oblique trajectory angles in robotic stereo-electroencephalography. J Neurosurg. 2020;135(1):245-254. doi:10.3171/2020.5.JNS20975

26. Tandon N, Tong BA, Friedman ER, et al. Analysis of Morbidity and Outcomes Associated With Use of Subdural Grids vs Stereoelectroencephalography in Patients With Intractable Epilepsy. JAMA Neurol. 2019;76(6):672-681. doi:10.1001/jamaneurol.2019.0098

27. Pieters TA, Conner CR, Tandon N. Recursive grid partitioning on a cortical surface model: an optimized technique for the localization of implanted subdural electrodes. J Neurosurg. 2013;118(5):1086-1097. doi:10.3171/2013.2.JNS121450

28. Dale AM, Fischl B, Sereno MI. Cortical Surface-Based Analysis: I. Segmentation and Surface Reconstruction. Neuroimage. 1999;9(2):179-194. doi:10.1006/nimg.1998.0395

29. Purcell JJ, Shea J, Rapp B. Beyond the VWFA: The orthography-semantics interface in spelling and reading. Cogn Neuropsychol. 2014;31(0):482-510.

doi:10.1080/02643294.2014.909399

30. McCarty MJ, Woolnough O, Mosher JC, Seymour J, Tandon N. The Listening Zone of Human Electrocorticographic Field Potential Recordings. bioRxiv. Published online 2021. doi:10.1101/2021.10.22.465519 